\title{
Introduction to the Revised and Expanded Edition
}

\begin{abstract}
A frican Americans are not a homogeneous group. In 1790, the year of the first national census, the term "Negro" was current, and the majority of Negroes were slaves. Emancipation, migration, miscegenation, and education diversified the population to the extent that today the African American population is as diverse as the EuroAmerican population. Yet with all the diversity, a common cultural framework and a social history sustain the classification.

Thus a foreword to a book entitled African American Art and Artists must confront the challenge of definition - what is African American art? Is it more African than American? Where is it exhibited? These may seem naive questions, but they are often posed by those who are new to the work and its creators, particularly young people, the majority of whom have had little art education. During lean economic times the arts are the first to be eliminated from the curricula of public schools, and rare is the private school that includes artists of color in an art appreciation class. It is obvious, then, that this text by Samella Lewis is sorely needed.

When meeting a new acquaintance involves answering the question, What do you do? and I mention activities involving African American art, I often say that the art is more American than African, and that it is syncretistic - like jazz. Most people know what jazz is. They know that it is perhaps America's only indigenous art form, a fusion of African rhythms, European harmony, and, increasingly, Asian elements.

Samella Lewis spent her formative years in the Deep South. Influenced by the life experiences of W. E. B. DuBois (1868-1963), she is keenly aware of all the contradictions the African American artist must assimilate. DuBois was born and received his early education in Great Barrington, Massachusetts. His Caucasian mentor advised him to seek higher education in the South, however, in an all-African American community, where he could learn who he was and what to expect as an African American. He taught school in a poor rural community in Tennessee while he completed his studies at Fisk University in Nashville,
\end{abstract}


which prepared him well for graduate studies at Harvard, where he earned his Ph.D.

Samella Lewis traveled a comparable path, from Dillard University in New Orleans to Hampton Institute, now Hampton University, in Virginia. At Hampton she had the benefit of the wisdom and experience of a refugee from Nazi-controlled Austria, Viktor Louenfeld, to guide her progress as an artist-art historian through the contradictions of segregated African American institutions that were governed by Caucasians.

She withstood the resistance to her struggle for equality in African American institutions, survived minority faculty status at schools in upstate New York and in California, placed her own aspirations as a visual artist on the back burner while she advocated for African American artists seeking to be recognized and showcased, and created curricula that included art by artists of color in California institutions, only to see them disappear after she retired. As Floyd Coleman remarks in his foreword to the 1990 edition of this book, "Few can bring to African American art history experience, knowledge, and perspective equal to those of Samella Lewis. She has been in close and sensitive contact with African American artists for over fifty years." She knows intimately the ambivalence of those artists about African American identity and the Euro-American aesthetic and the conflict it brings to the creative process.

Where can this art be seen? The museums and galleries in the United States that feature works by African American artists are not numerous, but they exist, primarily in major cities. The permanent collections of some major museums contain stellar works by African American artists. Additionally, major retrospectives of works by the masters are organized from time to time, such as Over the Line: The Art and Life of Jacob Lawrence, organized by the Phillips Collection, Washington, D.C. There is no better example of transcendence of all the ambiguity and tensions the African American artist faces than Lawrence's life and work. The editors of the exhibition catalogue explain its title as one that

is meant to be evocative and allusive, utilizing both senses of the word over and implying that Lawrence and his art occupy a transitional, undefined, or liminal place in American culture. By alluding to a border...through the use of the word line, the title acknowledges the artistic and social climate in which the artist spent most of his professional life - in a culture that categorized difference in binary terms and attempted to clearly delineate between the two. But it is also meant to imply that in his art and life he attempted to transcend this situation, to negate and go beyond such limitations, and to deal with the fundamental complexities of modern life. 
(Peter T. Nesbett and Michelle DuBois, eds., Over the Line: The Art and Life of Jacob Lawrence, published in association with the Jacob and Gwendolyn Lawrence Foundation [Seattle: University of Washington Press, 2000], 11)

Finally, the challenge to African American artists today is to find ways to use both the spiritual and material powers of art in such a way that their expressions become a vehicle for the understanding of people. This text has been written, this book created, to facilitate that process.

\author{
Mary Jane Hewitt \\ Pacific Palisades, California
}


